\title{
Entrepreneurship Development in Micro and Small Enterprises (MSEs) Sector: An assessment of Financial Support Ecosystem
}

\author{
Prof. Shabir A Bhat \\ Professor, The Business School \\ University of Kashmir, Srinagar \\ Tel: +91-941-906-5899 E-mail: shabirb87@yahoo.com \\ Riyaz Ahmad Khan (Corresponding author) \\ Research Scholar \\ The Business School \\ University of Kashmir, Srinagar \\ Tel: +91-941-948-3272 E-mail: rakisin@gmail.com
}

\begin{abstract}
Received: February 20, 2014 Accepted: March 8, 2014 Published: March 14, 2014
doi:10.5296/csbm.v1i1.5151

URL: http://dx.doi.org/10.5296/csbm.v1i1.5151
\end{abstract}

\begin{abstract}
Financial support ecosystem means the availability and access of financial resources to Micro and Small Enterprises Sector and generally includes financial support in terms of consultation support services, government funding support, sufficient government subsidies available for new and growing enterprises, venture capital fund support, adequate financial support schemes available, social investment and other financing resources. Financial Support forms an important contextual environment factor for the establishment, growth and sustenance of the enterprises in Micro and Small Enterprises Sector. Absence of a positive financial support ecosystem has been reported as one of the major constraints for the overall entrepreneurship development in the MSEs Sector throughout the world economies. The present study aims to assess the existing financial support ecosystem for the Micro and Small Enterprises Sector in the state of Jammu and Kashmir against the parameters of sufficient supply of capital / funding, adequate number of financial support schemes, collateral security a big problem for MSEs in availing the finance and access to finance cumbersome due to complex procedures
\end{abstract}




\section{Macrothink}

and formalities. And on the basis of the findings suggest measures to improve the financial support ecosystem for the robust entrepreneurship development in Micro and Small Enterprises Sector in the State. Findings indicate that to the extent that the collateral security and procedural hiccups were streamlined and more supply of funds made available, there will be remarkable entrepreneurship development in the MSEs Sector of the State.

Keywords: Financial support ecosystem, Micro and Small Enterprises Sector (MSEs), Entrepreneurship development 


\section{Introduction}

The financial ecosystem, in addition to other contextual ecosystems, forms an important component of the macro or external environment for the overall entrepreneurship development in any economy. Financial ecosystem means the availability and access of financial resources to Micro and Small Enterprises Sector and generally includes financial support in terms of consultation support services, government funding support, sufficient government subsidies available for new and growing enterprises, venture capital fund support, adequate financial support schemes available, social investment and other financing resources. In the contemporary literature on entrepreneurship, macro or external factors are considered to be more central in the entrepreneurship development of any economy and among these macro or external factors the 'Financial Support Ecosystem' is considered to be the crucial factor having a significant impact on the overall entrepreneurship development process of economies throughout the world.

Today world is experiencing the entrepreneurial revolution. Economic and technological advancements have opened up a new horizon for entrepreneurship development. However, there are plenty of ecosystem constraints that an entrepreneur faces while exploring this huge entrepreneurial potential and among these raising start-up capital for a business venture is seen as a bigger constraint particularly for knowledge based and innovative ventures. Researchers point out that the financial environment existing in a particular economy results in an environment framework having a very strong influence on the development of entrepreneurs. All this necessities the importance of entrepreneurship development analyses through the lens of the 'financial support ecosystem' assessment setup also. However, very less number of studies throughout the world have been undertaken more particularly in developing countries in this direction.

It is in this setting, that the present study is being undertaken to assess the existing 'Financial Support Ecosystem' towards the entrepreneurship development in Micro and Small Enterprises (MSEs) Sector in the state of Jammu and Kashmir against the parameters of sufficient supply of capital/funding, adequate number of financial support schemes, collateral security a big problem for MSEs in availing the finance/schemes and access to finance/schemes cumbersome due to complex procedures and formalities as shown in the Figure I. The results of this study shall pave the way for more research for the improvement of the overall financial support ecosystem towards the entrepreneurship development in Micro and Small Enterprises Sector in the State. 


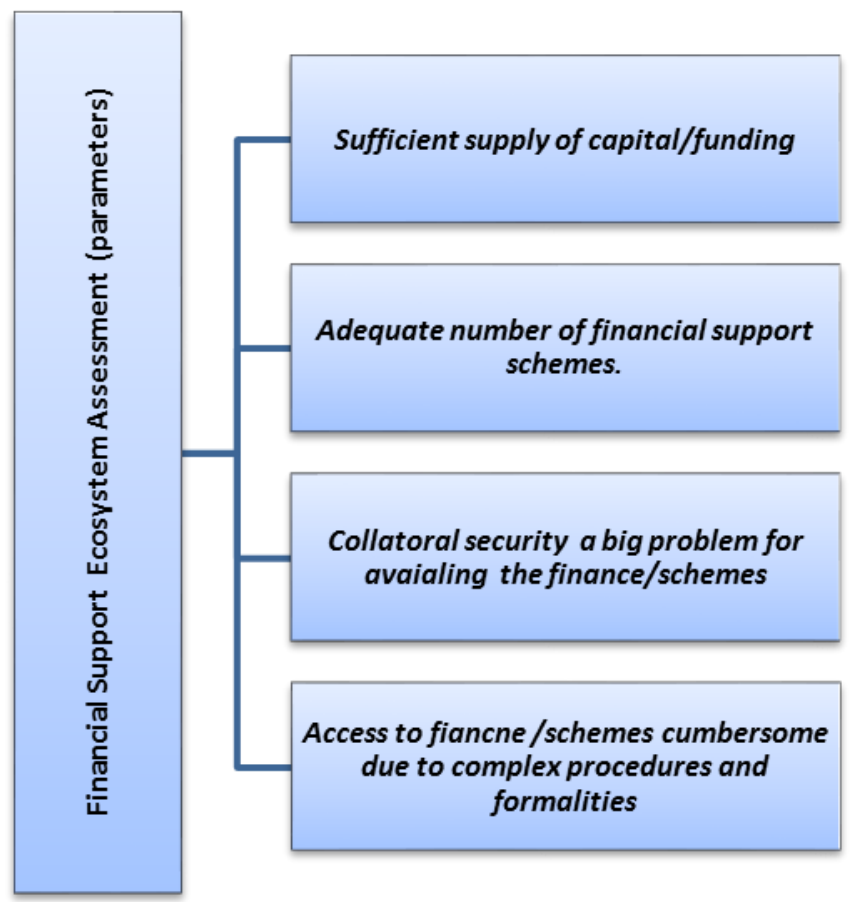

Figure 1. Financial Support Ecosystem Assessment Parameters

\section{Literature Review}

There is strong evidence that environment plays a very significant role in creation of an entrepreneurial venture (Hannan \& Freeman, 1977). Environmental variables matter not only to provide opportunities to exploit the imperfect markets as argued in the approach advocated by economists, but also in the sense that different environments are more or less conducive for entrepreneurial activities to flourish ((Stevenson \& Jarillo,1990,van de Ven,1993). Thus if entrepreneurship is the individual's response to a situation, i.e. the environment around him, and creation of an organization is essential for carrying through that response: the entrepreneur, environment and the organization must be regarded as crucial elements of any framework relating to entrepreneurship. They are indispensably linked to and continuously influence one another at different stages of entrepreneurial development. There are complex, bi-directional, interwoven and dynamic causal relationships among these constructs where some may have dominant influences over others, depending on the stage in the life cycle of the entrepreneurial venture.

The Financial /Capital School of Thought is based on the capital-seeking process. The search for seed and growth capital is the entire focus of this school (Brophy and Shulman, 1992; Erikson, 2002). Venture capital process is vital to an entrepreneur's development. This school of thought views the entire entrepreneurial venture from a financial management perspective.

Following an extensive study of entrepreneurship in 21 countries, Reynolds, Hay, Bygrave, Camp and Autio (2000) concluded that successful entrepreneurial activity is strongly associated with economic growth. Their research was subsumed under the "Global Entrepreneurship Monitor (GEM), a joint research initiative conducted by Babson College and London Business School and supported by the Kauffman Center for Entrepreneurial 
Leadership. Their findings, based on surveys of the adult population of each country, and the use of standardized national data, supported their conceptual model depicting the role of the entrepreneurial process in a country's economic development. The GEM Conceptual Model suggests that the social-cultural-political context within a country must foster certain "General National Framework Conditions," which can generate not only the opportunities for entrepreneurship but also the capacity for entrepreneurship -in particular, the skills and motivation necessary to succeed. Together, the entrepreneurship opportunities, on the one hand, and the skills and motivation, on the other, lead to business dynamics that yield creative destruction, a process in which new firms are created and older, less efficient firms are destroyed. The overall result for a country is economic growth. Of the eight "General National Framework Conditions" listed, the three that Reynolds et.al. (2000) highlighted as especially important are the availability of financing for new entrepreneurs, the need for government policies which are supportive of entrepreneurial efforts, and the opportunities for education and training in entrepreneurship. Entrepreneurial activity responds to internal country factors 'Entrepreneurial Framework Conditions' (EFCs) and external factors 'General National Framework Conditions' (GNFCs) that intervene between the emergence and expansion of new firms (Bosma et al.2008). Among the GNFCs, the Global Entrepreneurship Monitor (GEM) model includes external trade openness, the role of the government, market efficiency, technology intensity, physical infrastructure, management skills, labor market structure and institutional regulations. The EFCs that may affect the creation and development of new firms according to the GEM model , are financial support, government policies and programmes, education and training ,research and development (R\&D) transfer, commercial and professional infrastructure, international market openness, access to physical infrastructure, cultural and social norms, and intellectual property rights protection. However, internal and external factors can positively or negatively influence the overall entrepreneurship activities depending on the interpersonal relationships of entrepreneurs (Hoang and Antoncic 2003) and the inter organizational relationships between public and private institutions (Rodrik 2007). This supports Van de Ven's (1993) argument that studies are deficient if they focus exclusively on the characteristics and behavior of entrepreneurs without taking into account the environment and individual interaction.

There is a relatively small but growing body of research that examines the characteristics of regions in relation to entrepreneurial activity. Bruno and Tyebjee (1982) reviewed a number of studies and created an extensive list of environmental factors believed to be associated with entrepreneurship. These include venture capital availability, technically skilled labor force, proximity of universities, and availability of supporting services, among others. However, Bruno and Tyebjee concluded that much of the knowledge about environmental influence on entrepreneurial activity was based on anecdotal evidence, case histories and folklore. They argued that the existing research lacked a theoretical perspective and reflected a number of methodological difficulties.

This leads us to a general consensus that spatial conditions greatly influence new firm formation rates and that "the local social and economic milieu is the most important in fostering new firm formation." (Garofoli 1994, p. 391). Accordingly attention needs to be 
given to spatial conditions that is context- specific (macro environment) aspects when studying entrepreneurship as these are likely to have an influence on the entrepreneurial process itself and entrepreneurial activity in the regions (Sabine Muller, 2011). Jill S. Taylor (2006) in his study 'what makes a region entrepreneurial?' identifies five areas in which policymakers can direct efforts to increase entrepreneurial activity in a region: human capital, financial capital, tax and regulatory climate, physical infrastructure, and business culture and entrepreneurial climate. The immediate environment and relations, for example, with family, networks and role models therefore have an important influence on entrepreneurial activity (Julien, 2007)

Number of research studies have been undertaken on spatial characteristics and underlying mechanisms influencing (positively/negatively) the process of entrepreneurship and new enterprise formation rates: Environmental policies and support incentives, for example -foster technical knowledge base ,encouraging entrepreneurial activity, government support and policies, local empowerment, elimination of legal and administrative obstacles, entrepreneurial expertise/support services has positive effect (Kangasharju 2000; Chrisman et al.2002; O'Gorman and Kautonen 2004; Belso Martinez 2005; Li and Matlay 2006; Caliendo and Kritikos 2010). Socioeconomic conditions like availability of human capital (Davidsson et al.1994; Georgellis and Wall 2000; Kalantaridis and Bika2006; Audretsch et al.2010. Availability and access to financial capital for example local banks, angel investors, seed capital has also positive effect on entrepreneurship (Florida and Kenney 1988a; Malecki 1997; Audretsch and Keilbach 2004; Naude et al.2008). Wennekers and Thurik (2001) and De (2001) suggest a role for government in stimulating cultural or social capital and creating the appropriate institutional framework at the country level to address the supply side of entrepreneurship, i.e., focusing on the number of people who have the motivation, the financial means and the skills to launch a new business. From the findings of their international benchmarking study of entrepreneurial activity, Reynolds et al. (1999) recommended that governments should focus their effort on creating a culture that validates and promotes entrepreneurship throughout society and develops a capacity within the population to recognize and pursue opportunity. They should target policies and programs specifically at the entrepreneurial sector( rather than at aiming to improve the overall national business context), and to increase the overall education level of the population, specifically ensuring that entrepreneurship training is readily accessible to develop the skills and capabilities to start a business.

Mohammed S. Chowdhury (2007) conducted a study to investigate the constraints that entrepreneurs face in small and medium enterprises (SMEs) in Bangladesh. The findings of this study indicated that to the extent that the political stability and the rule of law were enforced, infrastructure facilities were improved, and corruptions were rooted out, education and trainings were imparted, and financial help was provided, new and energetic entrepreneurs, for the development of SMEs, would emerge in the country.

In a study comparing new firms in Poland, Slovakia, Romania, Russia and Ukraine, Johnson et al. (2000) establish that insecure property rights, in addition to weaknesses of macroeconomic stability and inadequate financing, inhibit the development of the private 
sector.

Harvie (2004) suggests that for SMEs in Asia to fully participate in the process of globalization, they must develop capacities that will enable them to compete in global markets. As early as 1997 at the APEC meeting in Ottawa, these were highlighted as: access to markets, technology, financing, information and Government has a big role to play in this.

In a case study covering internal and external factors affecting entrepreneurial success of SMEs in Indonesia, Susanto (2005) found that entrepreneurship development needs to be managed in a centralized, integrated and comprehensive manner in one agency. The case of Indonesia was that it was too dependent on external factors that included lack of funding, high interest rates, high taxation, and burdensome government requirements in seeking support. While the case study confirmed that a lack of knowledge and structural support could be constraining factors for entrepreneurs, the influence of the government to hinder entrepreneurship was far greater.

Bhasin (2007) studied the policy Singapore implemented to foster entrepreneurship. Policy measures promoting risk taking include changing the mindset through education, creating an environment that accepts failure, allowing for free expression, which induces innovation and very strong financial incentives, and tax breaks that increase entrepreneurial risk taking.

The government policies in India regarding small business are too complex to understand and this leads to stifling of the environment for small entrepreneurs. There exists a limited and diversified understanding of factors and the decision process that leads a person towards entrepreneurship (Markman et al., 2002). Entrepreneurship has grown slowly in India because of lack of funding (Huetter, 2007).

Minton (2006) reports that lack of long-term capital availability through banking channels, and absence of a properly organized and functioning capital and bond market impede the growth of entrepreneurship in Bangladesh. In addition, inadequate government efforts and incentives for entrepreneurial development appear to have retarded the process of entrepreneurship development in Bangladesh (Begum, 1993).Government should introduce "Startup enterprise Development Scheme (SEDS) to provide support for funding small ventures .government should establish a small medium micro enterprises hub (SMEH) in Bangladesh. SMEH is a concept of setting up support centers and developing framework for exploring, managing, financing small SMEs development practices. The strategy is to create awareness through information, advice, training, counseling, creating public private partnership, a sense of responsibility of becoming self-supporting, and finally promoting networks or clusters.

\section{Objectives}

The main objectives of the study were as follows:

1) To assess the existing financial support ecosystem for the MSEs Sector in the State of Jammu and Kashmir.

2) To focus on the role of financial support ecosystem in entrepreneurship development of 
the MSEs Sector.

3) To suggest measures for the improvement in the financial support ecosystem for the overall entrepreneurship development in MSEs Sector of the State.

Scope of the Study:

The paper focuses on assessing the existing financial support ecosystem for the entrepreneurship development in Micro and Small Enterprises (MSEs) Sector in the Jammu and Kashmir State against the parameters of sufficient supply of capital / funding, adequate number of financial support schemes, collateral security a big problem for MSEs in availing the finance/schemes and access to finance/schemes cumbersome due to complex procedures and formalities.

\section{Research Methodology}

Primary data was collected through survey method from a reasonable representative sample of respondents (the existing entrepreneurs in Micro and Small Enterprises Sector) from the Jammu, Kashmir and Ladakh three regions of the state. For this purpose the method of 'Stratified Random Sampling' was used so as to provide equal representation to all the selected respondents from all the three regions of the State. The total functional registrations figure of Micro and Small enterprises (MSEs) since inception up to 2010 with the Directorate of Industries and Commerce Jammu/ Kashmir was taken as the total population. A total of 1145 respondents were selected out of this population as a sample for the said study. The respondents were asked to express their level of agreement/disagreement on 5-point Likert-scale ranging from strongly disagree to strongly agree. Mean, Standard Deviation and t-test were used to evaluate the responses of the respondents.

\section{Data Analysis and Findings}

Data collected was subjected to analysis by using SPSS software version 20.0 and the results obtained thereof, on the basis of the response of the representative respondents against the given parameters, are presented as follows:

\subsection{Financial Support Ecosystem Parametric indicators}

Table 1. Sufficient supply of capital / funding available for MSEs

\begin{tabular}{ccccc}
\hline Scale & Frequency & Percent & Valid Percent & Cumulative Percent \\
\hline SD & 169 & 14.8 & 14.8 & 14.8 \\
D & 403 & 35.2 & 35.2 & 50.0 \\
UD & 29 & 2.5 & 2.5 & 52.5 \\
A & 296 & 25.9 & 25.9 & 78.3 \\
SA & 248 & 21.7 & 21.7 & 100.0 \\
Total & 1145 & 100.0 & 100.0 & \\
\hline
\end{tabular}

Perusal of the Table 1 shows that there is a very thin (2.4\%) difference among the respondents in 


\section{Macrothink

their response against this indicator statement. From the table 1 it is observed that level of disagreement is a bit higher (50\%) than the level of agreement (47.6\%) as far as the response of the respondents on this indicator statement is concerned. Figure 2 provides graphical representation of findings below.

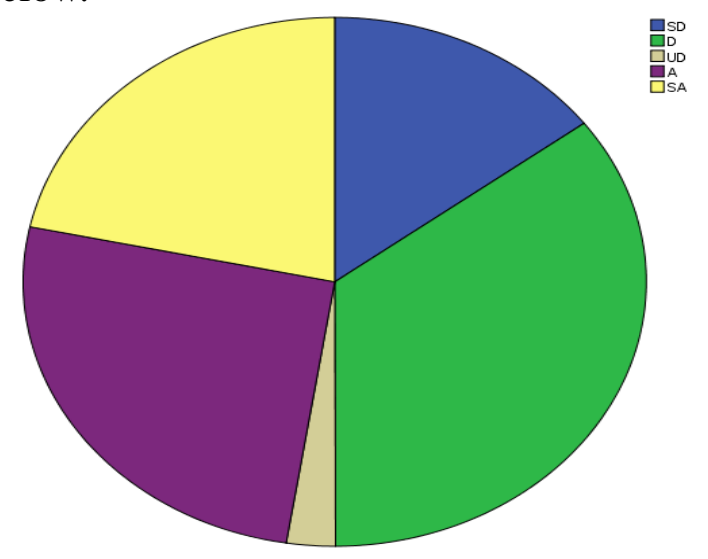

Figure 2. Sufficient supply of capital / funding available for MSEs sector

\subsection{Parametric Indicator, Adequate Financial Support Schemes Available for MSEs Sector}

Table 2. There are adequate financial support schemes available for MSEs Sector

\begin{tabular}{ccccc}
\hline Scale & Frequency & Percent & Valid Percent & Cumulative Percent \\
\hline SD & 148 & 12.9 & 12.9 & 12.9 \\
D & 221 & 19.3 & 19.3 & 32.2 \\
UD & 17 & 1.5 & 1.5 & 33.7 \\
A & 423 & 36.9 & 36.9 & 70.7 \\
SA & 336 & 29.3 & 29.3 & 100.0 \\
Total & 1145 & 100.0 & 100.0 & \\
\hline
\end{tabular}

Table 2 exhibits that majority $(66.2 \%)$ of the respondents believe that the financial support schemes available for MSEs Sector are adequate whereas $(32.2 \%)$ believe that the schemes are not adequate. Furthermore among the $(66.2 \%)$ respondents, $(29.3 \%)$ strongly agree and $(36.9 \%)$ only agree with the indicator statement. Figure 3 depicts the results graphically on a pie chart.

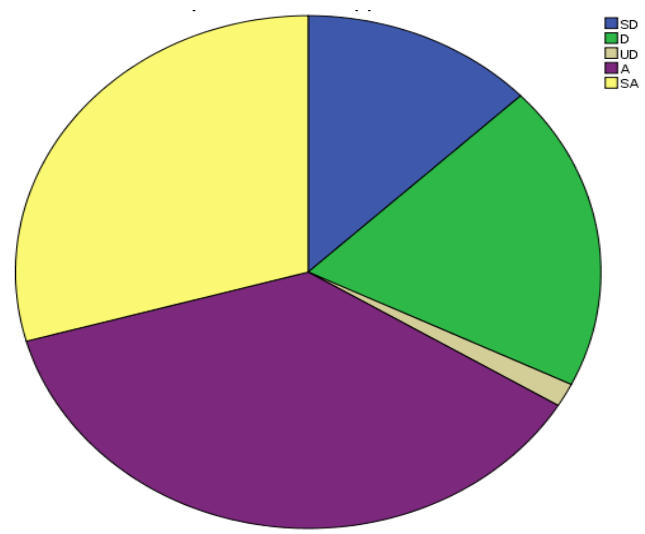

Figure 3. There are adequate financial support schemes available for MSEs sector 
5.3 Parametric Indicator, Collateral Security is a Big Problem for MSEs Sector

Table 3. Collateral security is a big problem for MSEs Sector in availing the finances/ schemes

\begin{tabular}{ccccc}
\hline Scale & Frequency & Percent & Valid Percent & Cumulative Percent \\
\hline SD & 25 & 2.2 & 2.2 & 2.2 \\
D & 96 & 8.4 & 8.4 & 10.6 \\
UD & 46 & 4.0 & 4.0 & 14.6 \\
A & 346 & 30.2 & 30.2 & 44.8 \\
SA & 632 & 55.2 & 55.2 & 100.0 \\
Total & 1145 & 100.0 & 100.0 & \\
\hline
\end{tabular}

The findings in the Table 3 illustrate that the highest number $(85.4 \%)$ of the respondents agree with the indicator statement whereas very few (10.4\%) of them disagree. In this case, the difference $(74.8 \%)$ is swooping one in favour of the statement. Moreover, $(55.2 \%)$ of the respondents strongly agreeing with the statement clearly displays the highest level of agreement in this case. Figure 4 shows the results graphically.

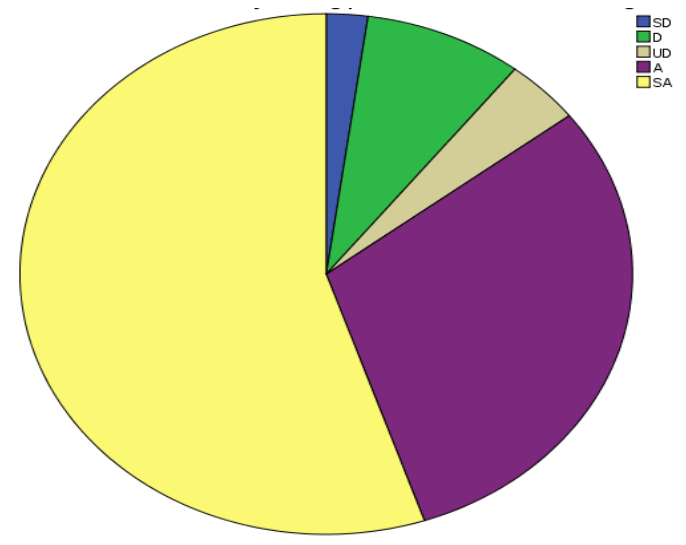

Figure 4. Collateral security is a big problem for MSEs in availing the finances/ Schemes

5.4 Parametric Indicator, Access to Finance is Cumbersome Due to Complex Procedures and Formalities

Table 4. Access to finance/schemes is cumbersome due to complex procedures and formalities

\begin{tabular}{ccccc}
\hline Scale & Frequency & Percent & Valid Percent & Cumulative Percent \\
\hline SD & 33 & 2.9 & 2.9 & 2.9 \\
D & 164 & 14.3 & 14.3 & 17.2 \\
UD & 52 & 4.5 & 4.5 & 21.7 \\
A & 331 & 28.9 & 28.9 & 50.7 \\
SA & 565 & 49.3 & 49.3 & 100.0 \\
Total & 1145 & 100.0 & 100.0 & \\
\hline
\end{tabular}




\section{Macrothink}

Review of the Table 4 shows that most of the (78.2\%) of the respondents show agreement with the indicator statement. The important thing to note here is that among the $(78.2 \%)$ of respondents, $(49.3 \%)$ strongly agree with the statement whereas $(28.9 \%)$ agree only with the statement. This clearly illustrates that the level of agreement is very much strong with the indicator statement. Figure 5 gives graphical presentation of the findings.

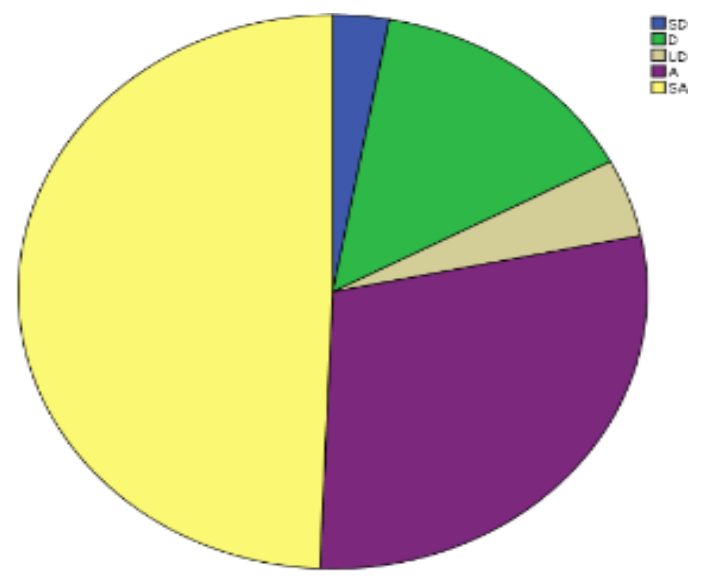

Figure 5. Access to finance/schemes is cumbersome due to complex procedures and formalities

5.5 Mean, Std. Deviation and Parametric T-Test to Assess the Overall Financial Support Ecosystem Existing for MSEs Sector in the State

Table 5. Mean, Standard deviation and t-test for assessing the overall Financial Support Ecosystem existing for the MSEs Sector

\begin{tabular}{lccc}
\hline Parameters & $t^{*}$ & Mean & Std. Deviation \\
\hline $\begin{array}{l}\text { 1. Sufficient supply of capital / funding available. } \\
\text { 2. Adequate number of financial support schemes. }\end{array}$ & 71.655 & 3.04 & 1.438 \\
$\begin{array}{l}\text { 3. Collateral security a big problem for MSEs in } \\
\text { availing the finance/schemes. }\end{array}$ & 117.951 & 4.50 & 1.414 \\
$\begin{array}{l}\text { 4. Access to finance/schemes cumbersome due to } \\
\quad \text { complex procedures and formalities. }\end{array}$ & 141.471 & 4.28 & 1.169 \\
\end{tabular}

$D f=1144 \quad * 95 \%$ Confidence Interval Level of Significance 20.005

Table 5 exhibits that the supply of funds/capital for the MSEs Sector is not sufficient $(\mathrm{t}=71.655)$. Findings show a startling response regarding the availability of financial support schemes for MSEs Sector, $(t=83.855)$ indicates that financial support scheme are adequate. While analyzing collateral security aspects, it has been observed that 'it is a big problem for entrepreneurs in MSEs Sector for availing the finance and schemes $(\mathrm{t}=117.951)$. Further the response on the parameter 'formalities and procedures for availing the finance/scheme' reveals that there is a greater need to streamline the procedures and reduce the formalities for the making the Financial Support Ecosystem positive towards the overall entrepreneurship development in the MSEs Sector of the State $(t=141.471)$. 


\section{Conclusion}

The results obtained out of the above analysis clearly indicate that the existing 'Financial Support Ecosystem' for MSEs Sector in the State is not adequate resulting in the poor entrepreneurship development of the State MSEs Sector in all the three regions of Jammu, Kashmir and Ladakh. The impact of each of the parameters taken to assess the financial support ecosystem can be explored further towards the overall entrepreneurship development across the sectors, by undertaking further research in this direction.

\section{Suggestions}

In order to make the 'Financial Support Ecosystem' encouraging for the overall entrepreneurship development in the MSEs Sector of the State, following few suggestions are put forth:

1) Financial support policies and schemes for MSEs Sector should be sect oral and not generic in nature, interest free, zero collateral security, transparent with simple norms and procedures, easily accessible etc. For this purpose other alternatives like interest free lending, micro financing, angel financing etc. should be taken into consideration while working out financial support policies and schemes especially for startup Micro and Small Enterprises (MSEs) Sector of the State.

2) In view of the importance of Micro and Small Enterprises(MSEs) Sector for the overall economic development of the state and the specific requirements of this Sector, it is suggested that the State Government should establish a separate micro financing agency 'MSE Bank' or else ensure that every financial/banking institution operational in the State should have a separate branch network 'MSE Branches' catering to the financial and other related requirements of the Micro and Small Enterprises Sector in the State.

3) Involvement of MSEs Sector representatives and stakeholders while devising any financial support policy, programme or scheme.

4) For the easy access and proper movement of financial schemes and other financial support services an apt implementation structure for MSEs Sector should be established.

5) To make 'Financial Support Ecosystem' more result oriented and sustainable, a proper follow-up mechanism should be linked with each and every MSMEs financial support initiative.

\section{References}

Audretsch, D. B., \& Keilbach, M. (2004). Entrepreneurship capital and economic $\begin{array}{llll}\text { performance. } & \text { Regional } & \text { Studies, } & \text { 38(8), }\end{array}$ http://dx.doi.org/10.1080/0034340042000280956

Audretsch, D., Dohse, D., \& Niebuhr, A. (2010). Cultural diversity and entrepreneurship: a regional analysis for Germany. Annals of Regional Science, 45(1), 55-85. http://dx.doi.org/10.1007/s00168-009-0291-x 
Begum, R. (1993). Entrepreneurship in small scale industries: a case study of engineering units. Dhaka University Journal of Business Studies, 14(1), 159-68.

Belso Martinez, J. A. (2005). Equilibrium entrepreneurship rate, economic development and growth, Evidence from Spanish regions. Entrepreneurship and Regional Development, 17(2), 145-161. http://dx.doi.org/10.1080/08985620500032633

Bhasin, B. (2007). Fostering Entrepreneurship: Developing a Risk-taking Culture in Singapore. New England Journal of Entrepreneurship, 10(2).

Bosma, N., Jones, K., Autio, E., \& Levie, J. (2008). Global Entrepreneurship Monitor: 2007 Executive Report. Babson College, London Business School and Global Entrepreneurship Research Consortium.

Brophy, D. J., \& Shulman, J. M. (1992). A Financial Perspective on Entrepreneurship Research. Entrepreneurship Theory and Practice, 61-17.

Bruno, A. V., \& Tyebjee, T. T. (1982). The Environment for Entrepreneurship. In C. Kent, D. Sexton, \& K. Vesper (Eds.), Encyclopedia of Entrepreneurship (pp. 288-315). Englewood Cliffs, NJ: Prentice- Hall Inc.

Caliendo, M., \& Kritikos, A. S. (2010). Start-ups by the unemployed: characteristics, survival and direct employment effects. Small Business Economics, 35(1), 71-92. http://dx.doi.org/10.1007/s11187-009-9208-4

Chrisman, J. J., Elizabeth, G., \& Leo B. D. (2002). A Note on the Efficiency and Effectiveness of Outsider Assistance Programs in Rural Versus Non-Rural States. Entrepreneurship: Theory \& Practice, 26(3), 67-80.

De, Dennis (2001). Fostering Entrepreneurship in Europe. In A. Lundstrom \& L. Stevenson (Eds.), Entrepreneurship policy for the Future (pp. 107-128). Stockholm: Swedish Foundation for Small Business Research.

Erikson, T. (2002). Entrepreneurial Capital: The Energy venture's Most Important Asset and Competitive advantage. Journal of Business Venturing, 17(3), 275-290. http://dx.doi.org/10.1016/S0883-9026(00)00062-8

Florida, R. L., \& Kenney, M. (1988a). Venture capital- financed innovation and technological change in the USA. Research Policy, 17(3), 119-137. http://dx.doi.org/10.1016/0048-7333(88)90038-8

Garofoli, G. (1994). New Firm Formation and Regional Development- the Italian case. Regional Studies, 28(4), 381-393. http://dx.doi.org/10.1080/00343409412331348346

Georgellis, Y., \& Wall, H. J. (2000). What makes a region entrepreneurial? Evidence from Britain. Annals of Regional Science, 34(3), 385-403. http://dx.doi.org/10.1007/s001689900014

Hannan, M., \& Freeman, J. (1977). The population ecology of organizations. American Journal of Sociology, 82(5), 929-64. http://dx.doi.org/10.1086/226424 
Harvie, C. (2004). East Asian SME Capacity Building, Competitiveness and Market Opportunities in a Global Economy. Department of Economics, university of Wollongong, Working Paper 04-16.

Hoang, H., \& Antoncic, B. (2003). Network-Based Research in Entrepreneurship: A Critical Review. Journal of Business Venturing, 18, 165-187. http://dx.doi.org/10.1016/S0883-9026(02)00081-2

Huetter, B. (2007). India rising. SPIE Professional.

Jill, S. T. (2006). What Makes A Region Entrepreneurial: A Review of the Literature. U. S. Department of Commerce, Economic Development Administration: Published by Center for Economic Development, Maxine Goodman Levin College of Urban Affairs, Cleveland State University.

Johnson, S., McMillan, J., \& Woodruff, C. (2000). Entrepreneurs and the ordering of institutional reform. Economics of Transition, 8(1), 1-36. http://dx.doi.org/10.1111/1468-0351.00034

Julien, Pierre-Andre. (2007). A theory of local entrepreneurship in the knowledge economy. Cheltenham, Edward Elgar Publishers. http://dx.doi.org/10.4337/9781847208750

Jun, L., \& Harry, M. (2006). Chinese entrepreneurship and small business development: an overview and research agenda. Journal of Small Business and Enterprise Development, 13(2), 248. http://dx.doi.org/10.1108/14626000610665953

Kalantaridis, C., \& Bika, Z. (2006). In-migrant entrepreneurship in rural England: Beyond local embeddedness. Entrepreneurship and Regional Development, 18(2), 109-131. http://dx.doi.org/10.1080/08985620500510174

Kangasharju, A. (2000). Regional variations in firm formation: Panel and cross-section data evidence from Finland. Papers in Regional Science, 79(4), 355-373. http://dx.doi.org/10.1007/PL00011482

Malecki, E. J. (1997). Technology and Economic Development. Harlow, Addison Wesley Longman.

Markman, G., Balkin, D., \& Baron, R. (2002). Inventors and New Venture Formation: The Effects of General Self-Efficacy and Regretful Thinking.

Minton, A. A. (2006). SMEs in Bangladesh. CACCI Journal, 1(1).

Mohammed, S. C. (2007). Overcoming entrepreneurship development constraints: the case of Bangladesh. Journal of Enterprising Communities: People and Places in the Global Economy, 1(3),

Naude, W., Gries, T., Wood, E., \& Meintjies, A. (2008). Regional determinants of entrepreneurial start-ups in a developing country. Entrepreneurship and Regional Development, 20(2), 111-124. http://dx.doi.org/10.1080/08985620701631498 


\section{Macrothink

O'Gorman, C., \& Kautonen, M. (2004). Policies to promote new knowledge-intensive industrial agglomerations. Entrepreneurship and Regional Development, 16(6), 459-479. http://dx.doi.org/10.1080/0898562042000224369

Reynolds, P. R., Michael, H., \& Camp, S. M. (1999). Global Entrepreneurship Monitor: 1999 Executive Report. Babson College, Kauffman Foundation and London Business School.

Reynolds, Paul R., Hay, M., Bygrave, W. D., Camp, S. M., \& Autio, E. (2000). Global Entrepreneurship Monitor: 2000 Executive Report. Kauffman center for Entrepreneurial Leadership.

Rodrik, D. (2007). One Economics, Many Recipes: Globalization, Institutions and Economic Growth. Princeton and Oxford: Princeton University Press.

Sabine M. (2011). Entrepreneurship and regional Development: A Literature Review. 6th European Conference on Innovation and Entrepreneurship, Robert Gordon University, Aberdeen, Scotland, 15-16 September 2011.

Stevenson, H. H., \& Jarillo, J. C. (1990). A paradigm of entrepreneurship: Entrepreneurial management. Strategic Management Journal, 11(Special Issue), 17-27.

Susanto, J. (2005). Creative Entrepreneurship in Indonesia: Problems, Strategies and Challenges- a case study. Study meeting on Creative Entrepreneurship, The Employers' Association of Indonesia, Asian Productivity Organization.

Van de Ven, A. H. (1993). The development of an infrastructure for entrepreneurship. Journal of Business Venturing, 211-230. http://dx.doi.org/10.1016/0883-9026(93)90028-4

Wennekers Sander, \& Roy Thurik. (2001). Institutions, entrepreneurship and economic performance. In Lundstrom, A., \& Stevenson, L. (Eds.), Entrepreneurship policy for the Future (pp. 51-87). Stockholm: Swedish Foundation for Small Business Research.

\section{Copyright Disclaimer}

Copyright reserved by the author(s).

This article is an open-access article distributed under the terms and conditions of the Creative Commons Attribution license (http://creativecommons.org/licenses/by/3.0/). 